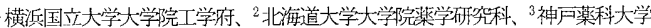
Analysis of Photoactivated Pharaonis Phoborthodopsin by Solid-State NMR Takudo Nishio (1), Youichi Tkeda (2), Akimori Wada (3), Izuru Kawamura (1), Naoki Kamo (2) and Akira Naito (1). (1: Graduate School of Engineering, Yokohama National University; 2: Graduate School of Pharmaceutical Sciences, Hokkaido University; 3: Kobe Pharmaceutical University)

Pharaonis phoborhodopsin (ppR) is a retinal protein in Natronomonas pharaonis and acts as a receptor of negative phototaxis. It forms a complex with its cognate transducer $p \mathrm{Htr} \Pi$ in the membranes and transmits light signals through protein-protein interaction. When $p \mathrm{pR}$ absorbs light energy at $498 \mathrm{~nm}$, the photoisomerization of retinal in $p \mathrm{pR}$ occurs to change $\mathrm{K}, \mathrm{L}, \mathrm{M}$, and $\mathrm{O}$ intermediates. Because $\mathrm{M}$ intermediate is known to transmit light signals to $p H$ trII, it is important to characterize the structure of M intermediate. Solid-state NMR study is a powerful means to gain insight into the local structure and dynamics under physiological conditions. We further introduced optical fiber to the top part of spinner in the NMR probe to irradiate light during solid-state NMR experiments. Because M intermediate has an absorption maximum at $390 \mathrm{~nm}$ and the thermal relaxation time to $\mathrm{O}$ intermediate is relatively long, it seemed to be able to trap M intermediate by illuminating the light with the wavelength from $450 \mathrm{~nm}$ to $600 \mathrm{~nm}$. Using this newly constructed apparatus, we tried to distinguish $p \mathrm{pR}$ in the dark from that in the light adapted state. The ${ }^{13} \mathrm{C}$ CP-MAS NMR spectrum of $\left[15,20^{-13} \mathrm{C}\right]$ retinal- $p p R$ was measured. The ${ }^{13} \mathrm{C}$ NMR signals of retinal in $p p R$ were observed in the first time at $13.5 \mathrm{ppm}$ and $162 \mathrm{ppm}$ in the dark adapted state. These signals are associated with those of retinal in bR and possible to change its chemical shift in the light adapted state. However, the difference was very small and further investigation is now underway.
$3 \mathrm{P} 229$

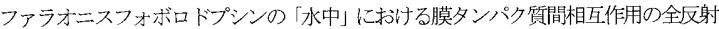
赤外分光法による解析

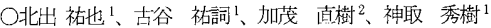

1名工大院·工、 ${ }^{2}$ 北大院・薬

Protein-protein interaction in the pharaonis phoborhodopsin-pHtrll complex under the aqueous environment studied by ATR-FTIR spectroscopy

Yuya Kitade (1), Yuji Furutani (1), Naoki Kamo (2), Hideki Kandori (1)(1: Department of Materials Science and Engineering, Nagoya Institute of Technology;2: Graduate School of Pharmaceutical Sciences, Hokkaido University)

Pharaonis phoborhodopsin (ppR; also called SRII) forms a 2:2 complex with its transducer, $\mathrm{pH}$ trII, in the membrane of Natronomonas pharaonis. $\quad$ p R absorbs green light $(\sim 500 \mathrm{~nm})$ to exhibit negative phototaxis. To understand the mechanism of signal transduction, the ppR-pHtrII system has been studied by various experimental methods. In the previous FTIR spectroscopy, we found that a hydrogen bond between Tyr199 in $p p R$ and Asn74 in $p \mathrm{Htr} \Pi$ is strengthened [1], and a temperature dependence of amide-I vibrations of $p \mathrm{pR}$ was observed only in the $p \mathrm{pR}-p \mathrm{H}$ trII complex [2]. While these data were used for explaining the signal transduction mechanism, it should be noted that hydrated films were prepared for these measurements to lower the water content in the transmission spectroscopy. Therefore, the question arises whether such structural changes occur under the aqueous environment as well

In this study, we applied attenuated total reflection (ATR) FTIR technique to the $p p \mathrm{R}-p \mathrm{H}$ trII complex. Consequently, the structural changes in the buffer solution were essentially similar to those observed in hydrated films. In addition, an interesting spectral alternation was newly found in the amide region, and we assigned these bands to $p H \operatorname{tr} \Pi$ by use of isotope-labeling with ${ }^{13} \mathrm{C}$ or ${ }^{15} \mathrm{~N}$. These structural changes are postulated to occur at the cytoplasmic region exposed to an aqueous phase, which may be related to activation of kinase domain in $p \mathrm{HtrII}$

References

[1] Fumutani et al Biochemistry 2005.

[2] Kamada et al. Biochemistry 2006.

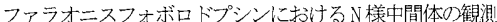

O阿部 孝行 ${ }^{1} 、$ 菊川 峰志、加茂 直樹

${ }^{1}$ 北大院・楽・生物物理、咷大創成研

\section{Observation of a $\mathrm{N}$-like intermediate in pharaonis phoborhodopsin}

Takayuki Abe(1), Takashi Kikukawa(2) and Naoki Kamo(1).(1:Graduate School of Pharmaceutical Sciences, 2:Creative Research Initiative "Sosei" (CRIS), Hokkaido University)

pharaonis phoborhodopsin ( $p \mathrm{pR}$; also called NpSRII) is a photoreceptor of negative photo-taxis in Natronomonas pharaonis. Many investigations of $p \mathrm{pR}$ have been carried out, because ppR can be expressed in $E$. coli membrane in a large amount (ca $5 \mathrm{mg} / \mathrm{L}$ of culture), and is much stable than phoborhodopsin from $H$. salinarum (HsSRII). The X-ray structure of $p \mathrm{pR}$ is very similar to that of bacteriorhodopsin ( $\mathrm{bR}$ ). The $p \mathrm{pR}$ photocycle is also similar to that of $\mathrm{bR}$ that is known as $\mathrm{bR}>\mathrm{K}>\mathrm{L} \rightarrow \mathrm{M}->\mathrm{N}>\mathrm{O}>\mathrm{bR}$ except for the slow decay of $\mathrm{M}$ and $\mathrm{O}$ of $p \mathrm{pR}$. Moreover the existence of $\mathrm{N}$-intermediate of the wild-type $p \mathrm{pR}$ has not been clearly identified yet, although Chizov et al. [1] mentioned the N-intermediate with very small amounts. Furutani et al. [2] described that a N-like protein structure in the wild-type $p \mathrm{ppR}$ was not observed at alkaline $\mathrm{pH}$ where $\mathrm{N}$-intermediate of $\mathrm{bR}$ is visible. In this study, we measured the photocycle of the wild-type $p \mathrm{pR}$ and mutants under various conditions, and found a N-like intermediate whose \&lambdamax is $480 \mathrm{~nm}$ when experiments were done under the condition where $\mathrm{M}$-decay became faster. The flash-photolysis data were analyzed by the irreversible sequential scheme of $\mathrm{P}_{0}>>\mathrm{P}_{1}>>>\mathrm{P}_{\mathrm{i}}>>>\mathrm{P}_{0}$ where $\mathrm{P}_{0}$ represents the original $p \mathrm{pR}$ and $\mathrm{P}_{\mathrm{i}}$ is the $\mathrm{i}$-th kinetically-defined intermediate. The $\mathrm{N}$-like intermediate appears as the equilibrium mixture of $\mathrm{M}$

[1] I. Chizhov et al, Biophys. J. 75:999-1009 (1998)

[2] Y, Furutani et al, Biophys. $J$ 83:3482-3489 (2002)
${ }^{13} \mathrm{C}$ 固体NMRによるファラオニスフォボロドプシンと複合体を形成したトランステ

$3 \mathrm{P} 231$-サータンパ質のダイナミクスとコンフォメーションの解析 ○大澤一弘 ${ }^{1}$ 池田 陽 ${ }^{2}$ 、川村 出 ${ }^{1}$ 、西尾 拓道 ${ }^{1}$ 加茂 直樹 2 、内藤 晶 '横国大·院・工、2北大・院・楽

Dynamics and conformation of transducer protein complexed with pharaonis phoborhodopsin as studied by ${ }^{13} \mathrm{C}$ solid state NMR

Kazuhiro Osawa(1), Yoichi Dkeda(2), Izuru Kawamura(1), Takudo Nishio(1), Naoki Kamo(2), Akira Naito(1).<br> (1)Graduate School of Engineering, Yokohama National University(2)Graduate School of Pharmaceutical Science, Hokkaido University

pharaonis phoborhodopsin $(p \mathrm{pR})$ in Natronomonas pharaonis is a negative phototaxis receptor and interacts with its cognate transducer protein $p \mathrm{HtrII}$ (pharaonis Halobacterial transducer II).$p \mathrm{HtrII}$ consists of tranmembrane region (TM1 and TM2) and cytoplasmic domain. The signal transduction from $p \mathrm{pR}$ to cytoplasm through $p \mathrm{Htrl}$ is triggered by isomerization of retinal induced by green light. It is important to clarify the interaction between $p p \mathrm{R}$ and $p \mathrm{HtrII}$ to gain insight into the mechanism of signal transduction. In this study, we have applied solid-state NMR spectroscopy to reveal local dynamics and structure using $\left[1^{-13} \mathrm{C}\right]$ Tyr-labeled $p \mathrm{HtrII}(1-159)$ because three Tyr residues exist in different region. ${ }^{13} \mathrm{C}$ NMR signals of [1-13 C] Tyr-labeled $p \mathrm{Htr} \Pi(1-159)$ complexed with $p \mathrm{pR}$ were observed in DD-MAS and CP-MAS NMR by light irradiation during measurements. ${ }^{13} \mathrm{C}$ DD-MAS NMR signals of $\left[1^{-13} \mathrm{C}\right]$ Tyr-labeled $p \mathrm{H}$ trII(1-159) complexed with $p \mathrm{pR}$ were partially decreased during light irradiation as compared with those of $\left[1^{-13} \mathrm{C}\right]$ Tyrlabeled pHtrII(1-159) complexed with $p p \mathrm{R}$ in the dark. ${ }^{13} \mathrm{C}$ CP-MAS NMR signals appeared at 177.1 and $175.9 \mathrm{ppm}$ ( $\alpha$-helix structure) and also decreased significantly during light irradiation. These results indicate that the cytoplasmic part of $p \mathrm{Htr} \Pi$ becomes rigid and the transmembrane region of $p \mathrm{Htr} I$ become flexible in the photo activated state. These findings consistant with our previous result of D75N-pHtrII system which is presumed photo activated state. 